\title{
A Contrastive Study of Bemba and Mambwe at Morphological Level
}

\author{
Chibwe Ronald Lumwanga*, John Lubinda, Hambaba Jimaima \\ The University of Zambia, Zambia
}

*Corresponding Author: Chibwe Ronald Lumwanga, The University of Zambia, Zambia

\begin{abstract}
A contrastive study between Bemba and Mambwe at Morphological level sought to find out how Standard Bemba and Rural Mambwe differ in terms of Morphology. The investigation was motivated by the proximity of Bemba and Mambwe speaking communities in Mbala District of Northern Province.
\end{abstract}

The researcher used qualitative research design because he sought to focus on words rather than on numbers. His methods were exploratory and descriptive: seeking to unearth the opinions, thoughts and feelings of the respondents. In this study, respondents were freely able to disclose their experiences, thoughts and feelings without constraint. This research design enabled the researcher to have an in-depth involvement by way of semi-structured interviews, focus-group discussions and observation. The researcher had an opportunity to follow up, through focus-group discussions, on the responses given earlier by the key informant who is very proficient in Mambwe. All the informants are proficient in the languages under study. The researcher's indepth involvement with the informants and his analysis and interpretation of the data has shaped the outcome of this study.

Many differences have manifested in Nominal Morphology and Verbal Morphology. Therefore, the conclusion is that these Morphological differences between the languages under study contribute to: (1) mutual unintelligibility between Bemba and Mambwe speakers who have had no experience of each other's language and (2) the absence of linguistic convergence between Bemba and Mambwe despite that these languages are spoken in the same geographical space.

Key Words: Standard Bemba (STDBEM), Rural Mambwe (RULMAM), Nominal Morphology, Verbal Morphology

\section{INTRODUCTION}

The proximity of Bemba and Mambwe speaking communities was the motivation of this study. By conducting the study to find out how the two languages differ morphologically, we had to establish (1) whether there is mutual intelligibility between speakers of these languages and (2) whether there is linguistic convergence between these languages. With regard to mutual intelligibility, Hudson (1980, p. 36) indicates that 'The degree of mutual intelligibility depends not just on a number of overlaps between items in two varieties, but on the qualities of the people concerned'. He mentions two of the qualities and these are motivation and experience.

The sociolinguistic landscape of Zambia contextualised this study: Zambia's geographical location makes it lie in the centre of the Bantu speaking area. Marten and Kula (2008) explain that the presentday Zambian Bantu languages resulted from several linguistic developments that ushered in the languages spoken today via the gradual process of migration, language contact and language shift over the last two millennia. Marten and Kula (2008) observe that the introduction of multiparty democracy brought a paradigm shift: emphasis has been placed on the promotion of the seven Zambian Regional Official Languages, namely: Lozi, Tonga, Nyanja, Lunda, Luvale, Kaonde and Bemba. These languages are important in relation to national, political and ethnic identities, communication, education and popular culture (Marten\&Kula 2008)

The Bantu languages account for 72 dialects in Zambia. These languages reduce to twenty-six (26) linguistic clusters, which are classified based on mutual intelligibility (Jimaima (2016); Kashoki \&Ohonnessian, 1978; Marten\&Kula, 2008; Wakumelo, 2013).

Bemba and Mambwe are spoken in Northern Province. The former is a language of wider communication and it is the Regional Official language whereas the latter is a minority language. 
But, perhaps, the most important observation made by Marten\&Kula is that ofZambia being a linguistically complex and dynamic country, with a range of different languages playing different roles in different contexts, and where language plays an important role in the construction and negotiation of social and national identities.

Spitulnik and Kashoki (2001) point out that the Bemba-speaking area stretches from the plateau between the escarpment of the Luangwa River to the east and the Luapula River to the west. In Zambia,Chibemba is principally spoken in the Northern, Copper-belt, Luapula and Muchinga Provinces. It is also spoken in the southern Democratic Republic of Congo (DRC) and southern Tanzania.

The Mambwe speaking people are found mainly in Mbala District of Zambia; they live directly on the junction of the routes between East and Central Africa. Mambwe is spoken in the north east of Northern Province (mainly in Mbala), South of Lake Tanganyika. It is also spoken in Tanzania's Rukwa Region, Sumbawanga District, the south eastern shore to the south of Lake Tanganyika, (Mambwe at Ethnologue, 2015).

The phrase "the Bemba" carries several meanings. It may designate people of Bemba origin, irrespective of where they live: whether in an urban area or the original rural Bemba area. They may encompass a much larger population that includes other different ethnic groups who with the Bemba constitute closely related ethno-linguistic clusters known as the Bemba speaking people of Zambia. There are over thirty Bemba clans named after animals or natural organisms such as the royal clan the people of the crocodile (Bena Ng'andu) or the Bena Bowa (Mushroom clan). The Bashimba (Leopard clan) or Bena Ngo living among the Bemba are part of the Bashimba People now living in Tanzania, Uganda and DR Congo.

According to the Census of Population and Housing (2010), Bemba was the most widely used language of communication spoken by 33.5 percent of the population in the country, followed by Nyanja and Tonga at 14.8 percent and 11.4 percent, respectively.

The Mambwe and Lungu belong to the same language group known as the Mambwe-Lungu. Thus, Mambwe and Lungu are dialects of this language group. According to Zambia Central Statistical Office (2002/2010), there are 500000 Mambwe speaking people.

There are many studies on Bemba, but very few on Mambwe. The studies on BembaincludeSpitulnik and Kashoki(2001), Kashoki (2000),Kashoki and Mann (1978), Mann (1999), Kashoki (1975), Kashoki (1977), Kashoki (1967), Musonda and Kashoki(1982),Kandeke(1990),Kangwa (2007), Kamfuli(2009) and Lumwanga (2015). Studies on Mambwe include Kashoki (1978), Halemba's (1994), Werner and Tucker (2009). With regard to these and other studies conducted on Bemba and Mambwe, the point is that there has not been a contrastive study of Standard Bemba and Rural Mambwe at morphological level. Given this scenario, the statement ofthe problem in question form is; 'How does the morphology of Standard Bemba (STDBEM) contrast with the morphology of Rural Mambwe (RULMAM)?

The purpose of this study was to contrast the morphology of Standard Bemba with the morphology of Rural Mambwe and to establish whether there is: (1) mutual intelligibility between the speakers of Bemba and Mambwe and (2) linguistic convergence between the two languages spoken in close proximity.

The Lexical Phonology framework developed by K.P. Mohanan and P. Kiparsky has informed this study (Udema, 2004). This is a theory in which morphological and phonological rules are brought together within a single framework and, therefore, it acts a base for analysing and interpreting the data. This study has also made use of the branch of linguistics known as Contrastive Linguistics. The data in Nominal Morphology and Verbal Morphology in the languages under investigation have been used to elicit the differences.

This study was conducted in Mbala District in the Northern Province. It is one of the eleven districts in the province and shares the border with Tanzania in the north and the east, Mpulungu District in the west and Senga Hill District in the South. This place was chosen as a research site because of the proximity of the Bemba and the Mambwe speaking communities: their languages are spoken in the same area; Bemba happens to be the Regional Official Languageused in the area. 
The study population consisted of all the people who are proficient in Bemba and Mambwe. It was good that the informants are proficient in the languages. This is because in a qualitative study it is important to select knowledgeable participants on the issue under investigation, (Kombo \& Tromp, 2006).

One key informant was used for the interviews and five participants (including the key informant) were engaged in focus-group discussions. With this study sample, the researcher was able to obtain the morphological differences between the languages under study and to conclude that theses morphological differences contribute to (1) mutual unintelligibility between the speakers of these languages and (2) the absence of linguistic convergence between Bemba and Mambwe

Five informants were selected from the study population. The objective of this sampling was to minimise, within the limitation of the cost, the gap between the values obtained from the sample and those prevalent in the larger population.

The researcher employed the interview schedule and focus group discussion. He also consulted academic books, scholarly journals and research reports.

This section presents the differences between the languages under studywith regard to Nominal morphology:

(1) The nouns in both STDBEM and RULMAM having different nominal prefixes, but with the same nominal stems. This category includes cognate words. It is worth indicating that STDBEM is an augmented language with forms like $\mathbf{u}$-mu-, $\mathbf{a}$-ba-, $\mathbf{i}$-mi- whereas RULMAM is a non-augmented language, as we shall note in the presentation.

This study reveals that STDBEM uses -ba-, nominal prefix class 2 for plural in the word a-ba-ntu which is written as abantu 'people', but RULMAM realises nominal prefix class 2 as a- in the word a- ntu which is written as antu 'people'. Illustrations of the differences are given below:

STDBEM

1

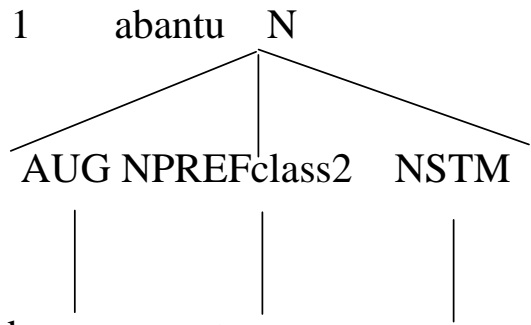

a ba ntu

\section{RULMAM}

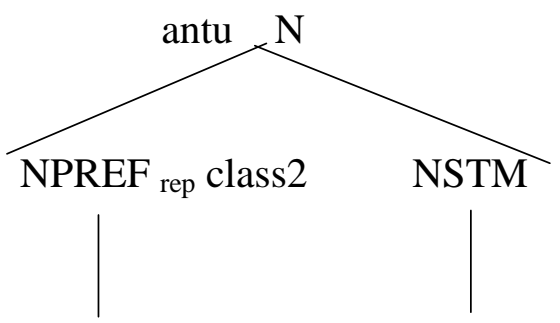

ntu

Similarly, -ba- is the nominal prefix in the STDBEM words: $\boldsymbol{a}$-ba-lumendo written as abalumendo 'boys' and $\boldsymbol{a}-\boldsymbol{b} \boldsymbol{a}-p a b i$ which is rendered as $a \boldsymbol{b a p a b i}$ 'persons of no royal blood or ordinary people'. Other words include $\boldsymbol{a}$-ba-eni (abeeni) 'guests', a-ba-kashana (abakashana) 'girls', a-ba-ice (abaice) 'children' whereas a- is the nominal prefix representing class 2 in the corresponding RULMAM words: a-lumendo (alumendo) 'boys' and $\boldsymbol{a}$-pabi written as apabi 'persons of no royal blood or ordinary people'. In this category, the cognate words include $\boldsymbol{a}$-enyi (aenyi) 'guests', a-kazyana (akazyana) 'girls', a-nce (ance) 'children'. Illustrations of the differences are below:

\section{STDBEM}

2

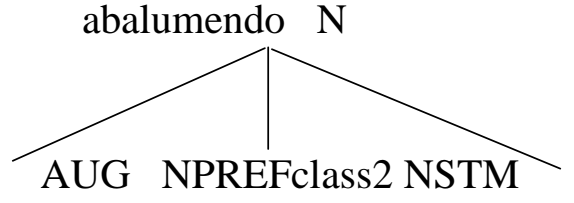

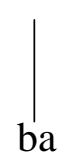<smiles>CC(C)(C)O</smiles> 

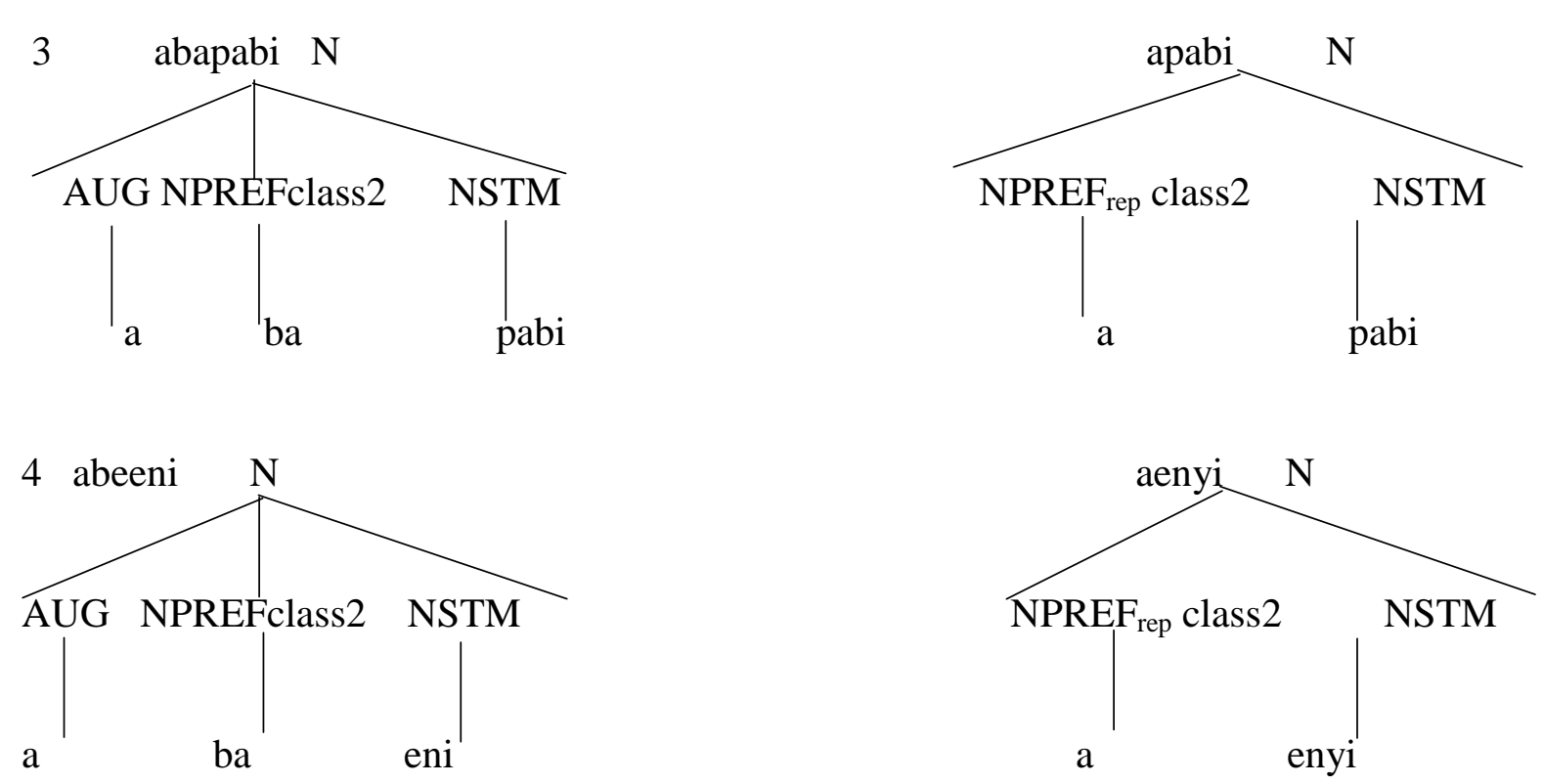

5
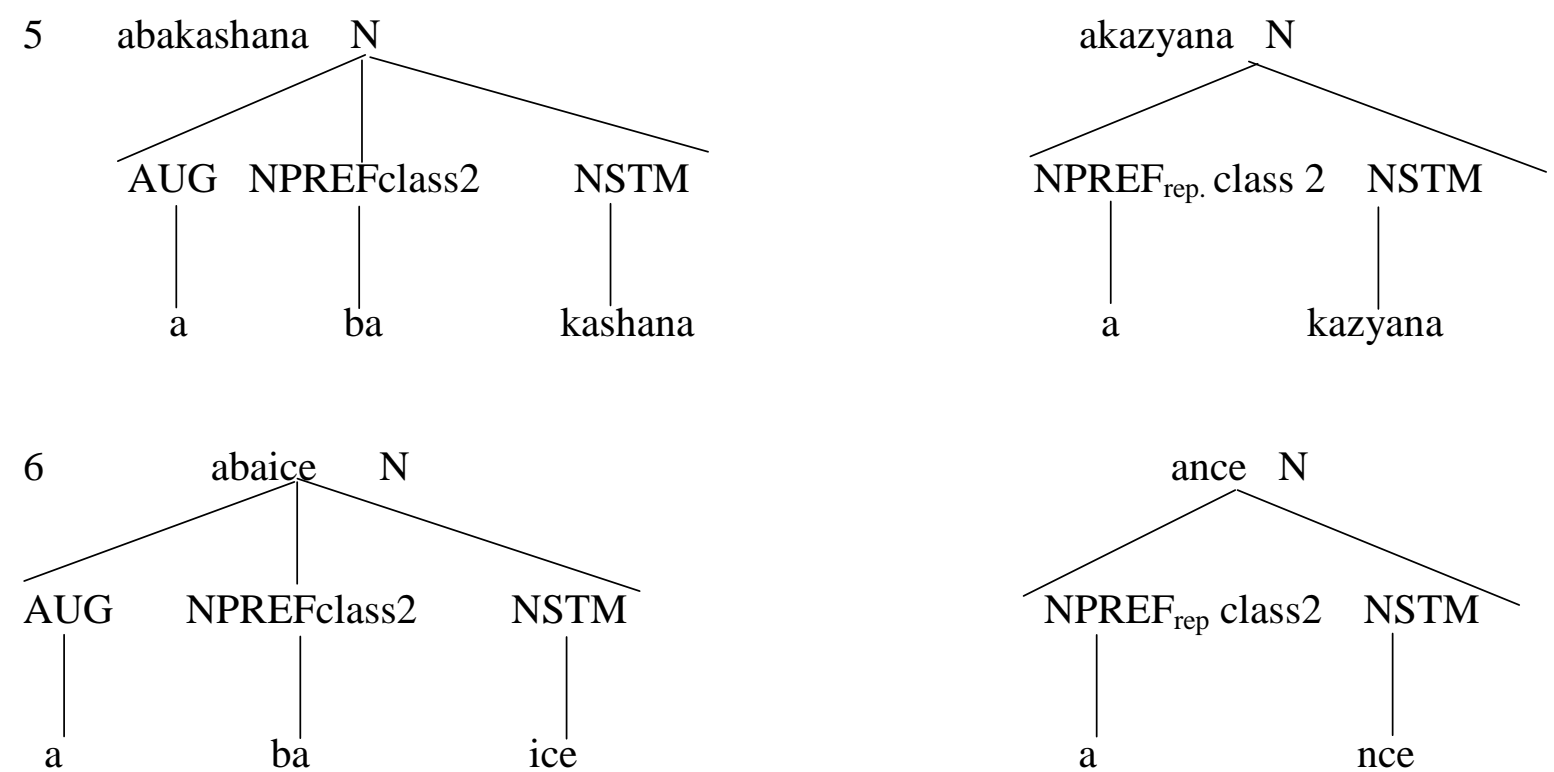

(2) The differences arise from the nouns in both STDBEM and RULMAM having the same nominal prefixes but with different nominal stems.

It is noted in this study that some nouns in STDBEM and RULMAM share the nominal prefixes class 1 -mu- (referring to people) and class 3 -mu- (referring to things), but have different nominal stems. In STDBEM, these stems include -anakashi, - ela, -tima, -shikale, -kashi, -shi and - shila. They follow the prefixes to form the nouns u-mu-anakashi (umwanakashi) 'woman', u-mu-ela(uleepuирa) (umwela) 'wind', u-mu-tima (umutima) 'heart', u-mu-shikale (umushikale) 'soldier' u-mu-kashi (umukashi) 'wife', u-mu-shi (umushi) 'village' and $u$-mu-shila (umushila) 'root'. The same nominal prefixes are followed by the corresponding RULMAM stems: - anaci, $-z a,-e n z o,-s i l i k a,-c i,-z i$, and - sisi to form the nouns mu-anaci (mwanaci) 'woman', $\boldsymbol{m u}$-za (muza) 'wind', mu-enzo (mwenzo) 'heart', $\boldsymbol{m u}$-silika (musilika) 'soldier' and $\boldsymbol{m u}$-ci(muci) 'wife', $\boldsymbol{m u}$-zi (muzi) 'village', mu-sisi (musisi) 'root', respectively.

Semivocalisation occurs in the words in 7 for both STDBEM and RULMAM, in 8 for (STDBEM) and in 9 for RULMAM, as noted in the illustrations below: 


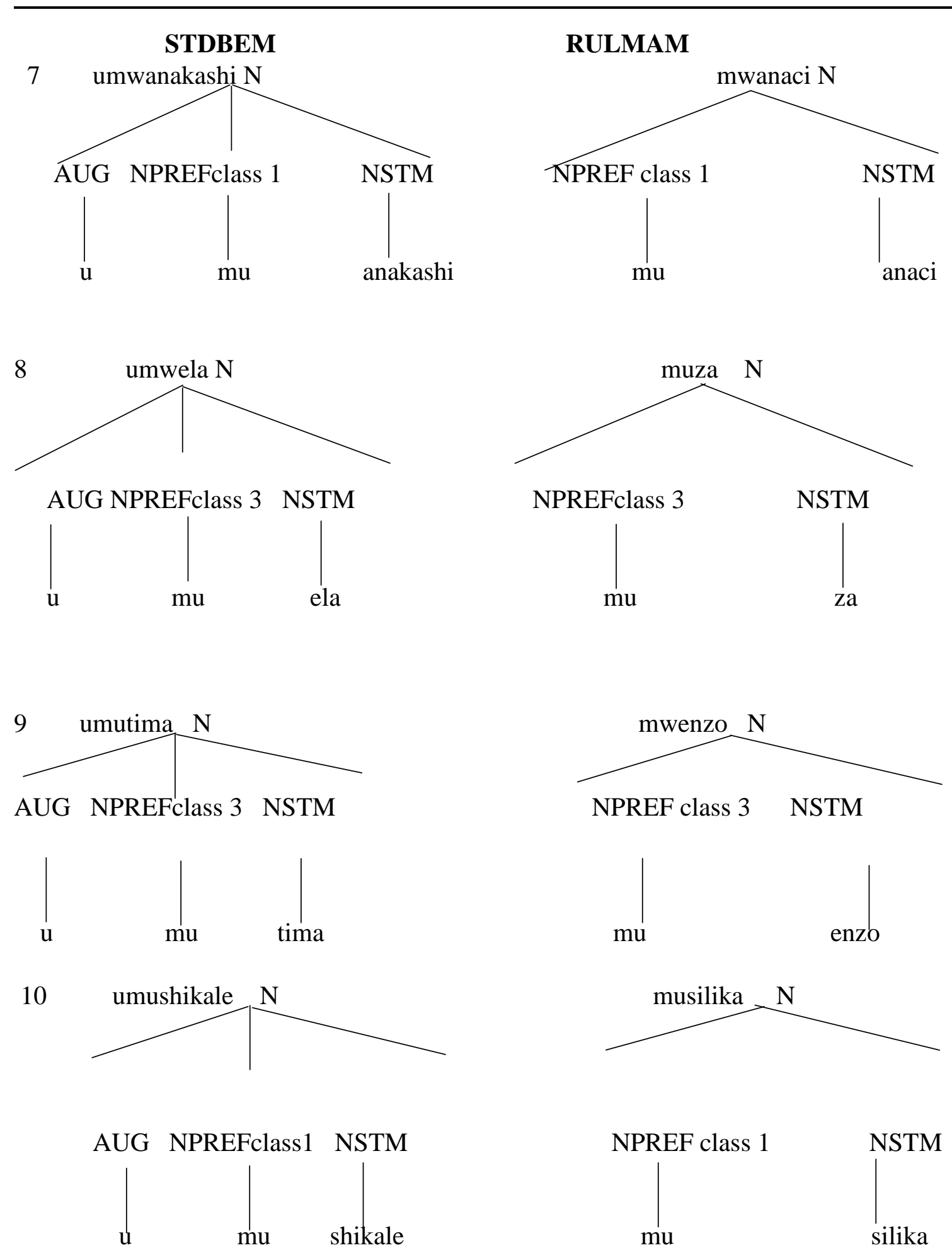

(3)Differences between STDBEM and RULMAM nouns manifest because of the nouns in STDBEM having the nominal prefixes and the nominal stems which are different from the nominal prefixes and the nominal stems, respectively, of the nouns in RULMAM

We note in this study that among many STDBEM nominal stems, which follow the nominal prefix class 8, -fi-, are-ponshi, - kondo, - umbu, - sabo, - puna and - kumpilo. These stems and the prefix -fi- which is preceded by the augment $\mathbf{i}$ - form the nouns ifiponshi 'gums', ifikondo 'toes', ifyumbu 'potatoes', ifisabo'crops', ifipuna 'seats' and ifikumpilo 'slashers'. The corresponding RULMAM nouns with vi- representing the nominal prefix class 8 are vimununyu 'gums', vikando 'toes', visela 'potatoes', visao 'crops', vilimba 'seats' and vipupo 'slashers'. Illustrations of the morphological differences are presented below: 
11

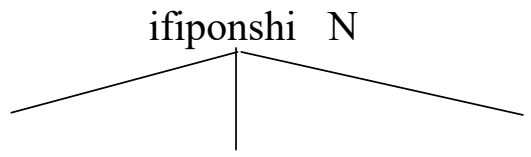

AUG NPREF class 8 NSTM

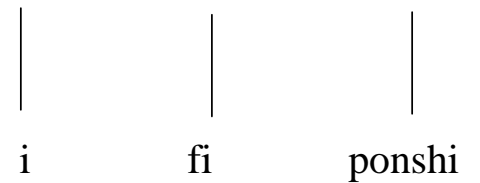

12

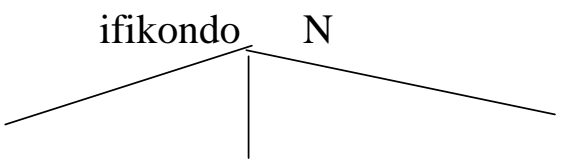

AUG NPREF class8 NSTM

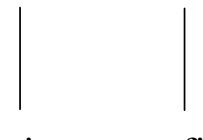

i fi

kondo

13

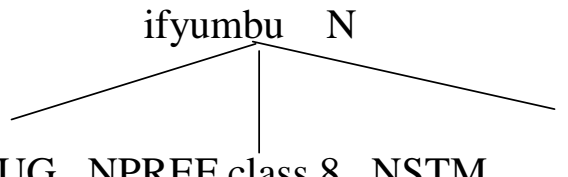

AUG NPREF class 8 NSTM<smiles>I[Te]I</smiles><smiles>C[18OH]</smiles>

14

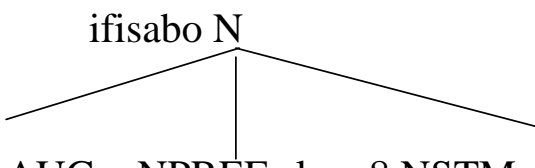

AUG NPREF class 8 NSTM
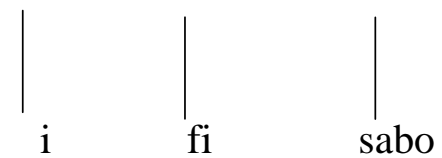

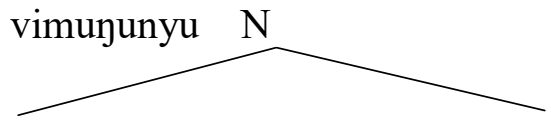

$\mathrm{NPREF}_{\text {rep. }}$ class 8 NSTM
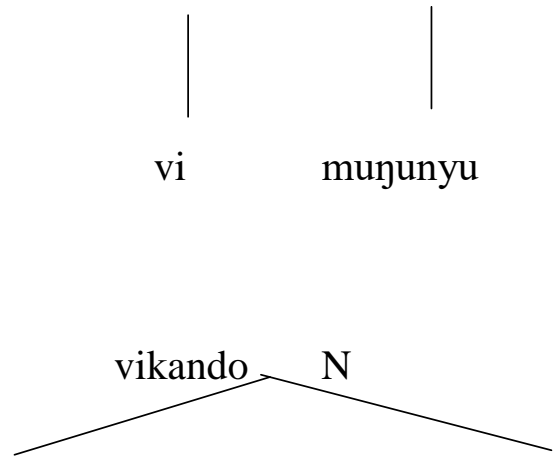

NPREF rep. class 8 NSTM
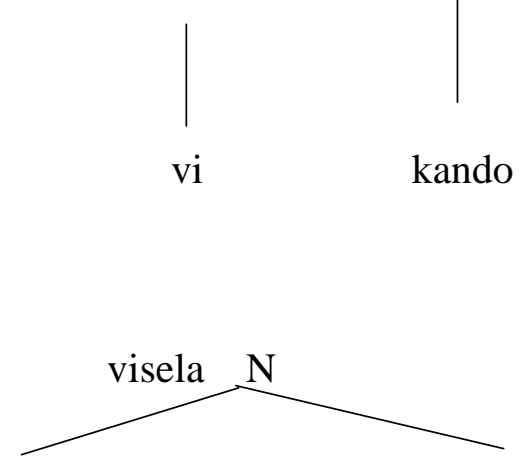

NPREF rep.class 8 NSTM
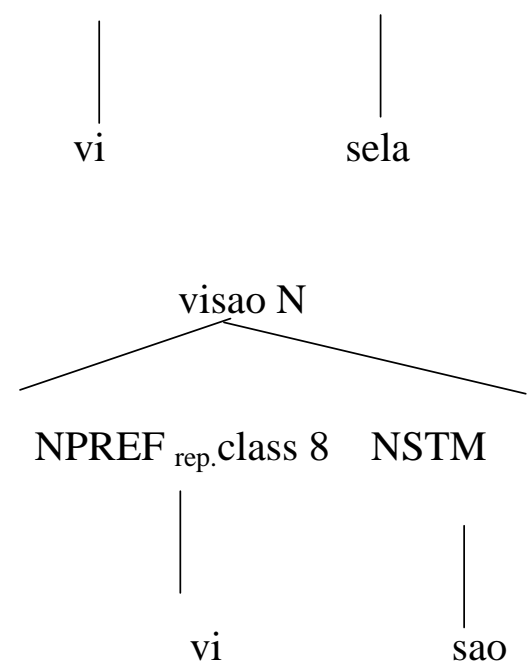

Semi vocalisation occurs in 13 in the STDBEM noun i-fi-umbu (ifyumbu).

\section{Key to abbreviations}

N: noun; AUG: augment; NPREF: nominal prefix; NSTM: nominal stem; STDBEM: standard Bemba; RULMAM: Rural Mambwe

With regard to Verbal Morphology, the differences have emerged in:

(1) Tenses, which are: the Present Simple Tense. Present Progressive (or Continuous) Tense, Posthodiernal (or Remote Future) Progressive Tense, among others. 


\section{Present Simple Tense}

This tense expresses habitual actions, permanent states and scientific facts. The study reveals some differences between STDBEM and RULMAM in relation to this tense.

The tense marker for the Present Simple Tense in STDBEM is -la-, as these verbs reflect:15(i) alanjipikila 'she/he cooks for me', 16 (i) alatema imiti 'he cuts tress',17(i)tulalimba imiti 'we plant tress', 18(i)balanandila 'they speak for me' while in RULMAM the tense marker for Present Simple Tense is -ka- as the corresponding RULMAM verbs manifest in 15(ii) akangelekela 'she/he cooks for me',16(ii)akaputula imiti 'he cuts trees',17(ii) tukalemá imiti 'we plant trees' and18(ii) yakamvwangila 'they speak for me'. There is also a difference in terms of subject markers: in the STDBEM verb in 18 (i), the subject marker is ba- 'they' whereas in the RULMAM verb in 18(ii) the subject marker is ya- 'they'. The verb stem in 15(i) is -ipika-'cook' and is immediately preceded by object marker -nj-meaning for me because the verb is applicative (nj-ipik-il-a) while the corresponding RULMAM verb stem in 15 (ii) is -eleka 'cook' which is also immediately preceded by the object marker ng meaning for me since the verb is applicative (ng-elek-el-a). The difference between the STDBEM consonant cluster /-nj-/ in 15(i) and the RULMAM consonant cluster /-ng-/ in 15(ii) arises from the rule in STDBEM, which states that "when $\mathbf{n}$ - (which is objective) is followed by a, e, or $\mathbf{i}, a / j$ / is inserted", (Sims, 1959:65). The verb stem -tema 'cut trees' in 16 (i) is STDBEM while - putula 'cut tress' is RULMAM, but we should indicate that the verb stem -putula is also used in STDBEM. The STDBEM verb stem in 17 (i) is -limba 'plant (trees)' whereas the corresponding RULMAM verb stem in 17 (ii) is -lemá 'plant (trees)'. In the STDBEM verb ba-la-n-land-il-a (balanandila) 'they speak for me', the verb stem is -landa 'speak'. It is noted that in the verb balanandila, the initial phoneme of the verb stem (landa), the voiced alveolar lateral /l/, becomes the voiced alveolar nasal /n/ by undergoinng progressive nasal assimilation (as can be seen in ba-lannand-il-a) in the environment after the voiced alveolar nasal $/ \mathbf{n} /$ which happens to be the object marker. The discontinuous applicative morpheme /il/ in the verb works in tandem with this object marker $/ \mathbf{n} /$. On the other hand, the verb stem in the corresponding RULMAM verb ya-ka-n-vwang-ila (yakanvwangila) 'they speak for me' is - vwanga 'speak'. The voiced alveolar nasal /n/immediately preceding the verb stem is the object marker and functions in conjunction with the applicative extension morpheme/-il-/. The object marker /n / which has been phonologically converted to the voiced bilabial nasal $/ \mathbf{m} /$ is phonetically assimilated to the voicedlabio-dental nasal [m] in order to make it homorganic with the voiced labio-dental fricative/v/ which immediately follows it. The phonetic transcription of yakamvwangila is [jakámvwángíla] 'they speak on my behalf of'.

Below is the illustration of one the morphological differences presented in the text:

15(i) alanjipikila (STDBEM)

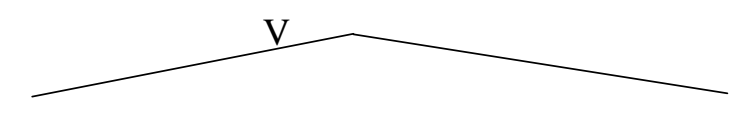

SM TM (PRES.HAB) OM VSTM (APP)

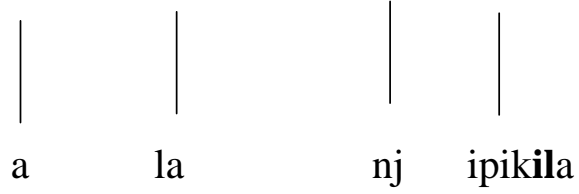

(ii) akangelekela (RULMAM)
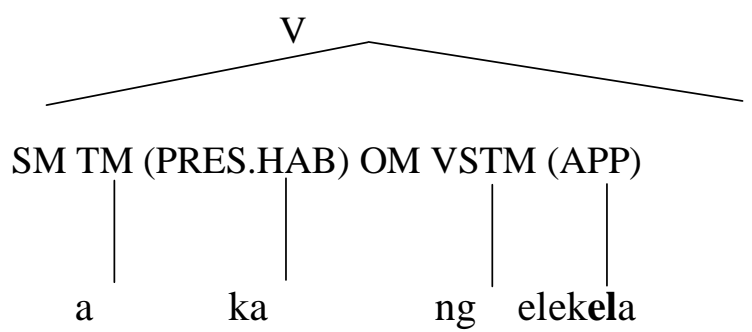
Gloss: she/he cooks for me

\section{Key to abbreviations}

SM: subject marker; TM: tense marker; PRE. HAB: present habitual; OM: object marker; VSTM: verb stem; APP: applicative

\section{Present Progressive (or Continuous) Tense}

This is the tense the speaker uses when talking about the activities happening now. With regard to this tense, the findings are that some differences between STDBEM and RULMAM manifest in relation to verbal elements. The study shows that the progressive aspect marker is -lee- 'are, is, or am' in these STDBEM verbs: baleeteya (umupila) 'they are playing (football)' in 19(i) and baleetamfya (inama) 'they are chasing(ananimal)' in 20(i) is different from the progressive aspect marker -ku- 'are, is ,or am' in the corresponding RULMAM verbsyakuteya (mpila) they are playing (football) in 19 (ii) and yakuzinga (inama) they are chasing (an animal) in 20 (ii). Differences also manifest in terms of the subject markers and verb stems. The STDBEM subject marker is $b a$ 'they' in 19 (i) and 20(i) whereas the subject marker in the corresponding RULMAM verbs in 19 (ii) and 20 (ii) is ya 'they'. The STDBEM verb stem -tamfya 'chase' in 20 (i) is different from the corresponding RULMAM verb stem: -zinga 'chase' in 20 (ii). The tree diagrams below are illustrations of the morphological differences:

19 (i) baleeteya umupila (STDBEM)

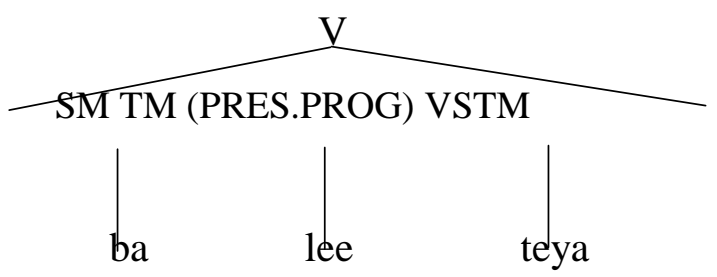

(ii) yakuteya mpila (RULMAM)
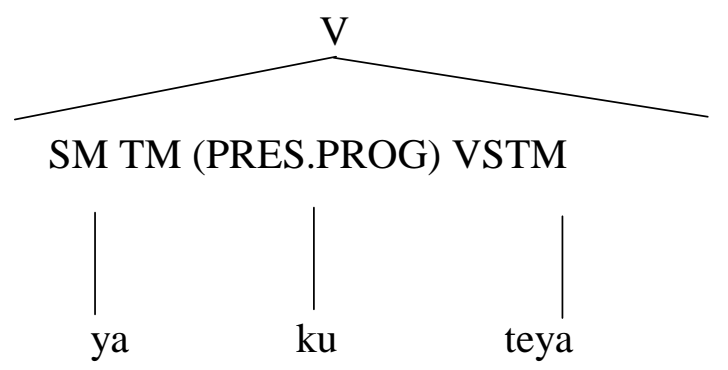

Gloss: they are playing (football)

Key to abbreviations

PRES. PROG: present progressive

\subsubsection{Posthodiernal (or Remote Future) Progressive Tense}

The encoder using this tense expresses the notion that the activity talked about will be progressing. The findings show that the verbal elements for STDBEM under this tense are subject markers, the tense marker for posthodiernal (or remote future). -ka- 'will/shall', the progressive aspect morphlaa- 'be' and the verb stem while for RULMAM they are: subject markers and the -lá- which is followed by the verb stem. Unlike the -la-for remote future (or posthodiernal) tense, the -la- in this tense is high-toned (-lá-) and represents the morphemes for futurity and progression or continuity of the activity.

In the STDBEM verbs bakalaangala 'they will/shall be playing' in 21(i), bakalaasenda 'they will/shall be carrying' in 22 (i) and bakalaaibukisha 'they will/shall be commemorating' in 23(i), the verbal elements are the subject marker $\boldsymbol{b} \boldsymbol{a}$ - 'they', the tense marker for remote future - $\boldsymbol{k} \boldsymbol{a}$ - 'will/shall', 
the progressive aspect morph -laa- 'be' and the verb stems: - (a)ngala 'play' in 21 (i) (in which the initial low central vowel /a/ in the verb stem has been absorbed by the long low central vowel /aa/ in the progressive aspect morph -laa- preceding the verb stem), - senda 'carry' in 22 (i) and - ibukisha 'commemorate' in 23 (i) while in the corresponding RULMAM verbs: yalácimya 'they will/shall be playing' in 21 (ii), yalásenda 'they will/shall be carrying' in 22 (ii) and yaláiusya 'they will/shall be commemorating' in 23(ii), the verbal elelments are: the subject marker ya- 'they', -the posthodiernal progressive tense marker lá- and the verb stems: - cimya'play in 21 (ii), - sénda'carry' in 22(ii) and iusya 'commemorate' in 23 (ii). The study also shows the difference between STDBEM and RULMAM with regard to the tense markers. In STDBEM, $-\boldsymbol{k} \boldsymbol{a}$ - 'will/shall' and the progressive aspect morph -laa- 'be' are used whereas in RULMAM, there is the cumulative morph -lá- realising both the remote future and the progressive aspect morphemes. The STDBEM verb stems - angala 'play' in 21(i),- ibukisha 'commemorate' in 23 (i) are different from these RULMAM verb stems:-cimya 'play' in 21(ii) and-iusya 'commemorate' in 23 (ii). The verb stems ibukisha in STDBEM and iusya in RULMAM are cognates.

The tree diagrams are illustrations of one of the differences discussed above:

21 (i) bakalaangala muma bumba (STDBEM)

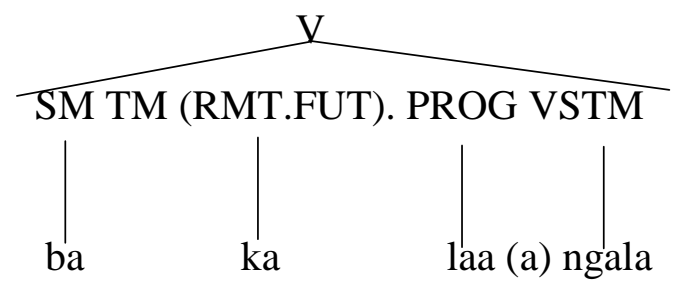

(ii) yalácimya muma umba (RULMAM)

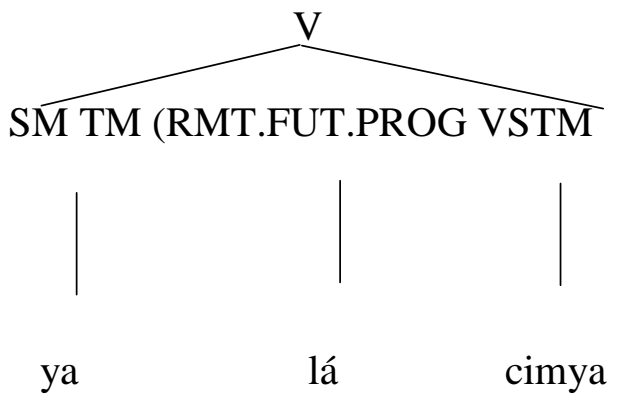

Gloss: they will/shall be playing in the teams

\section{Key to abbreviations}

RMT.FUT.PROG: remote future progressive; SM: subject marker; TM: tense marker; VSTM: verb stem

\section{Verbal Extensions}

We note the differences in relation to these verbal extensions: completive, frequentative, intensive and causative

\section{Completive Verbal Extensions}

A morph under this extension expresses the notion that the action of the verb to which it is attached is done completely. The completive verbal extension morphs are: -ilil-, -elel-, -inin- and -enen-. The findings are that in STDBEM the completive verbal extension morph -enen-is placed between the verb radical -pen- 'be or become mad' and the final vowel -a to form the completive verb penenena 'be or become completely mad' while in RULMAM the completive verbal extension morph -elel- is infixed between the verb radical -pen-'be or become mad' and the final vowel $-\mathbf{a}$ to derive the completive verb penelela 'be or become completely mad'; this is another difference. Similarly, the completive verbal extension morph -inin-is placed between the STDBEM verb stem -kam- 'dry up' 
and the final vowel $-\mathbf{a}$, to form the completive verb kaminina 'dry up completely' while in RULMAM the completive verbal extension morph -ilil- is placed between the verb radical -kam'dry up' and the final vowel -a to derive the completive verb kamilila 'dry up completely'. The same completive verbal extension morphs -inin- and -ilil- are noted in the STDBEM completive verb pininina 'be or become completely poor' and in the RULMAM completive verb pinilila 'be or become completely poor'. The findings, therefore, reveal that the completive verbal extension morphs for STDBEM are different from the completive verbal extension morphs for RULMAM.

\section{Frequentative Verb Extension}

The morpheme in this extension shows that the action of the verb to which its morph is attached is distributed widely because of repetition. The fact from this study is that the morphs -aul-for STDBEM and -ol-for RULMAM are used to derive verbs in this extension category. The findings show that in STDBEM the frequentative verbal extension morph - aul-is placed between the verb radical -ikat- 'touch' and the final vowel -a to derive the frequentative verb ikataula 'touch in many places' while between the RULMAM verb radical -lem- 'touch' andthe final vowel $-\mathbf{a}$, the frequentative verbal extension morph $-\boldsymbol{o l}$ - is infixed to form the frequentative verb lemola 'touch in many places. Another difference is noted in the STDBEM and RULMAM verbs which mean plant seeds in many places: Between the STDBEM verb radical -byal- 'plant seeds' and the final vowel -a, the frequentative verbal extension morph -aul- is placed to derive the frequentative verb byalaula 'plant seeds in many places'. In contrast to this, the corresponding RULMAM verb komela 'plant seeds' does not take the frequentative verbal extension morph -ol-; instead, it is repeated. In other words, the reduplication of this full morph komela is komelakomela, which conveys the notion of frequentativeness.

\section{Intensive Verbal Extension}

The morpheme in this verbal extension expresses intensification of the action of the verb to which its morph is attached. The morphs are - esh- or - ish-for STDBEM and - esy-or - isy-for RULMAM. The intesnsive verbal extension morph - $\boldsymbol{e s h}$ - is infixed between the STDBEM verb radical -beleng'read' and the final vowel -a to derive the intensive verb belengesh a 'read very much or too much'; the intial vowel of the intensive verbal extension morph - esh, the mid front vowel [e], harmonises well with the mid front vowel [e] in the verb radical (-beleng-). On the other hand, between the RULMAM verb radical -wazi- 'read'and the final vowel -a, the intensive verbal extension morph sy- is infixed to form the intensive verb wazisya 'read very much or too much'. The noticeable difference, here, is that the STDBEM intensive verbal extension morph begins with the mid front vowel [e] followed by the voiceless postalveolar fricative [ $\int$ ], but the RULMAM intensive verbal extension morph has the high front vowel [i] followed by the voiceless alveolar fricative [s] which is palatalised to [sj]. The findings also show that between the verb radical -lok- 'rain'and the final vowel -a, the STDBEM intensive verbal extension morph - esh- is placed to derive the intensive verb lokesha 'rain very much or too much' while the RULMAM intensive verbal extenstion morph -esy- is infixed between the verb radical -lok- 'rain' and the final vowel -a to form the intensive verb lokesya 'rain very much or too much.

\section{Causative Verbal Extension}

The morph attached to the verb radical in this extension indicates that the subject of the verb is caused to do something stated by the verb; the morph is the high front vowel / i /.

This study shows that between the STDBEM verb radical -lek- 'stop'and the final vowel $-\mathrm{a}$, the high front vowel /i/ is infixed to get lek-i-a, but the voiceless velar stop / $\mathbf{k} /$ in the verb radical is converted to the voiceless alveolar fricative /s / in the environment before the high front vowel /i/; the resultant form is lesia, and because of Semivocalisation the form becomes lesya: the presence of the voiced palatal approximant $[\mathbf{j}]$ in the form leads to the Palatalisation of the voiceless alveolar fricative $/ \mathbf{s} /$, and in STDBEM palatalisation of this consonant segment results in its Postalveolarisation. In other words, the voiceless alveolar fricative [s] becomes the voiceless postalveolar fricative $[\boldsymbol{j}]$ in the environment before the high front vowel [i], thereby forming the causative verb lesha 'cause to stop'. However, this is not the case in RULMAM in which the process terminates at the Palatalisation of the voiceless alveolar fricative [sj] resulting in the causative verb form lesia which becomes lesya cause to stop'. The distinction between these causative verbs is that the second syllable of the 
STDBEM verb lesha begins with the voiceless postalveolar fricative [ $]$ ] while the second syllable of the RULMAM verb lesya begins with the voiceless alveolar fricative /s/, which is palatalised [sj]. The same processes occur in relation to the STDBEM and RULMAM causative verbs lusha 'cause to vomit and lusya 'cause to vomit', respectively; both these verbs come from the verb root -luk'vomit'.

\section{Mood}

This section of the chapter analyses and interprets the findings in relation to the differences in the area of mood, which is viewed from the three standpoints, namely: imperative mood, subjunctive mood and indicative mood. Mood is "a term used in the theoretical and descriptive study of sentence/clause types and especially of the verbs they contain", (Crystal, 1991:223). In addition, Crystal indicates that, semantically, a wide range of meanings is involved, more especially the attitudes the speaker shows towards the factual content of the utterance. The study sought to find out the differences with regard to imperative mood. This is the mood dealing with identification of sentence types and usually seen in contrast to other types of mood such as indicative and others. An imperative usage refers to verbs or sentence/clause type usually used in expression of command, (Crystal, 2008; Mathews, 2005).

This study has noted that for the command to be executed immediately, the stem of the verb is used for the second person singular, (Sims, 1959). The following differences between STDBEM and RULMAM imperative attest to the foregoing fact.

\section{STDBEM}

24 sendá

25 cindá

26 isa

27isala (iciibi)

\section{RULMAM}

sénda

cína

iza

yala (cisasa)
Gloss

carry/take

dance

come

In 24 , it is noted that the difference between sendá and sénda in STDBEM and RULMAM, respectively, is that in the STDBEM word sendá carry/take' the second syllable carries High Tone(HT) while in the RULMAM word sénda, the first syllable carries HT. In 25, the STDBEM and RULMAM words are different: while in the STDBEM word cindá, the second syllable begins with a nasal complex /nd/, the second syllable in the RULMAM word cina begins with the voiced alveolar nasal $/ \mathrm{n} /$. The other difference noted in the words is that in the STDBEM word cindáin (25), the second syllable carriesHT whereas in the RULMAM word cina in (25), the first syllable carries HT. In 26, the second syllable in the STDBEM word isa (i-sa) begins with the voiceless alveolar fricative /s/ while the second syllable in the RULMAM word iza (i-za) begins with the voiced alveolar fricative /z/. In 27, the STDBEM imperative verb isala 'close' is completely different from the RULMAM verb stem yala 'close'

It is also evident from this study that the command addressed to the second person plural requires the adjunction of the morph -inito the verb stem (i.e. the singular form), (Sims, 1959). Below are illustrations of the morphological differences from the findings:

\begin{tabular}{llc} 
STDBEM & \multicolumn{1}{c}{ RULMAM } & Gloss \\
28cinda-ini $\rightarrow$ cindeeni & cina-ini $\rightarrow$ cinini & dance \\
29palama-ini $\rightarrow$ palameeni & palama-ini $\rightarrow$ palamini & come near (er) \\
30iingila-ini $\rightarrow$ ingileeni & ingila-ini $\rightarrow$ ingilini & enter \\
31isa-ini $\rightarrow$ iseeni & iza-ini $\rightarrow$ izini & come \\
32imanina-ini $\rightarrow$ imanineeni & imilila-ini $\rightarrow$ imililini & stand up \\
33twala-ini $\rightarrow$ twaleeni & twala-ini $\rightarrow$ twalini & take
\end{tabular}

It is evident from this study that in the items from 28 to 33 under STDBEM, the second person plural imperative verbs undergo vowel coalescence when the low central vowel /a/ in the verb stems merge with the initial high front vowel /i/ in the suffix -ini (i.e., the morph realising plural or honorific 
morpheme or both). In RULMAM, the terminal low central vowel /a/ in the verb stems is dropped or lost as the plural morph -ini is added.

It is also noted from this study that in the negative imperative, the pronouns are used with all persons together with the negative particle'i', (Sims, 1959). Illustrations of the morphological differences in the negative imperatives are shown below:

34 (i) eebomba (STDBEM)

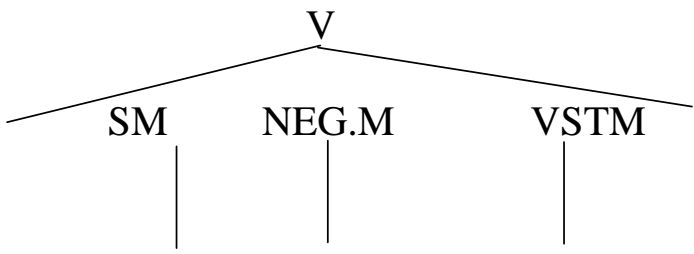

a $\quad$ i bomba

(ii) ataomba (RULMAM)

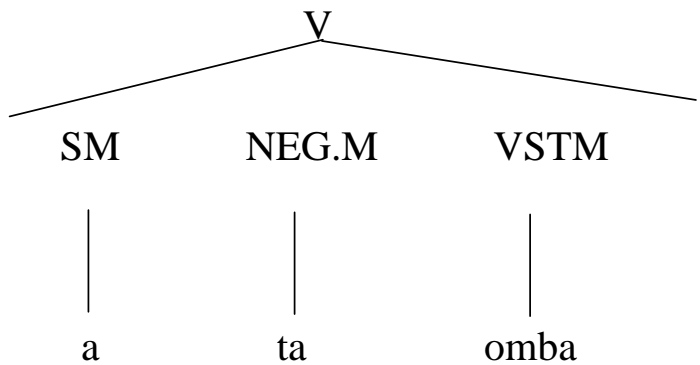

Gloss: let him/ her not work 35 (i) wiisa (STDBEM)

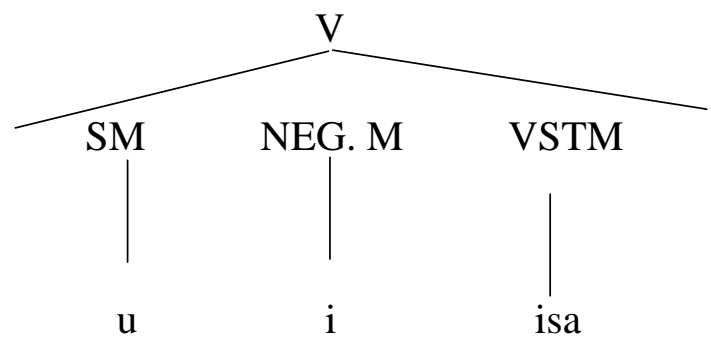

(ii) utiza (RULMAM)

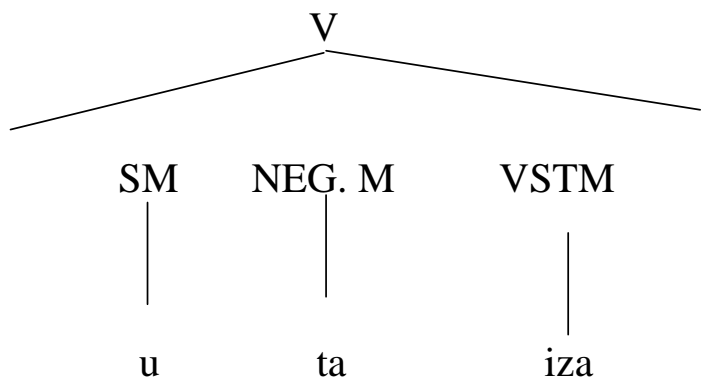

Gloss: don't come

36 (i) eeingila (STDBEM)

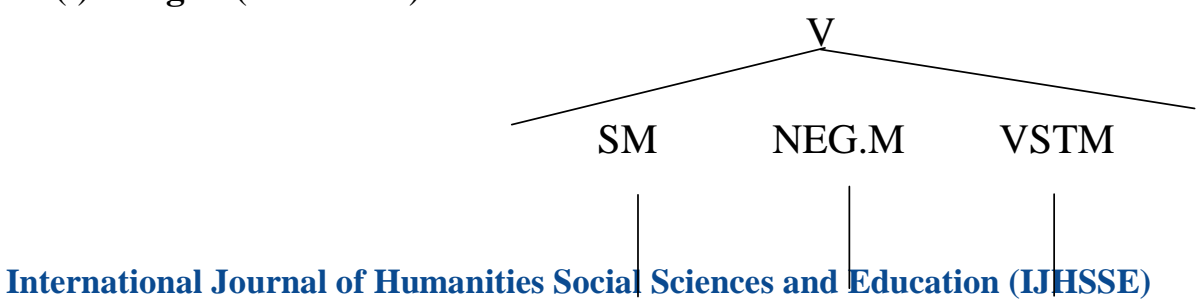




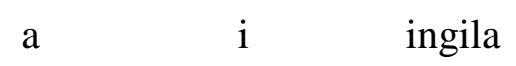

(ii) atingila (RULMAM)

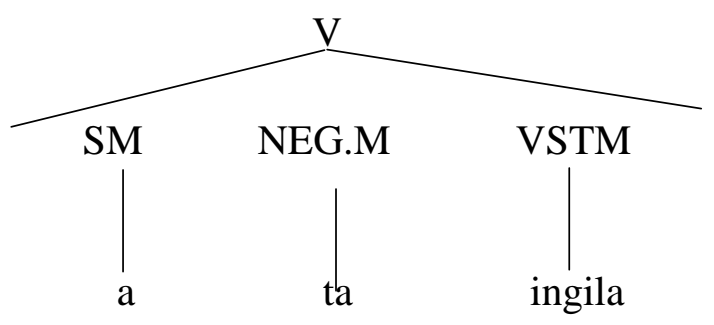

Gloss: let him/her not enter

37 (i) mwilya (STDBEM)

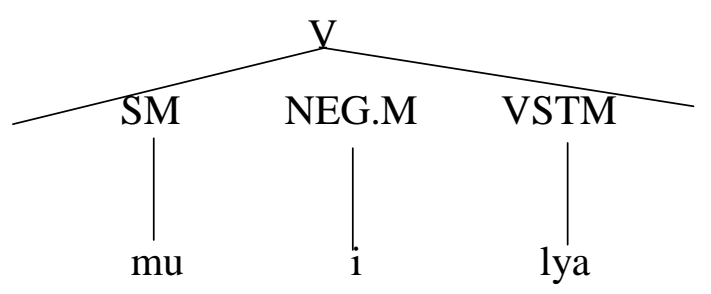

(ii) mutalya (RULMAM)

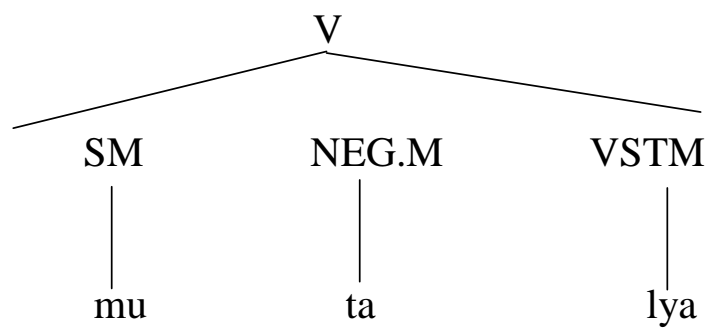

Gloss: don't eat

38 (i) beeima (STDBEM)

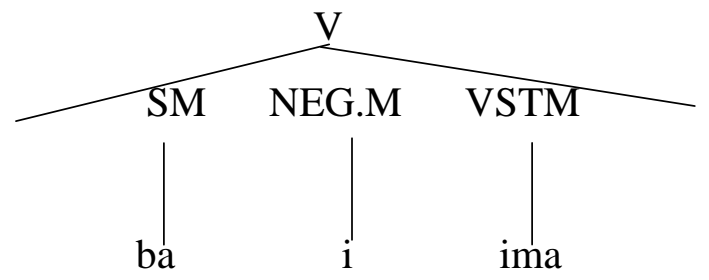

(ii) yatakatuka (RULMAM)

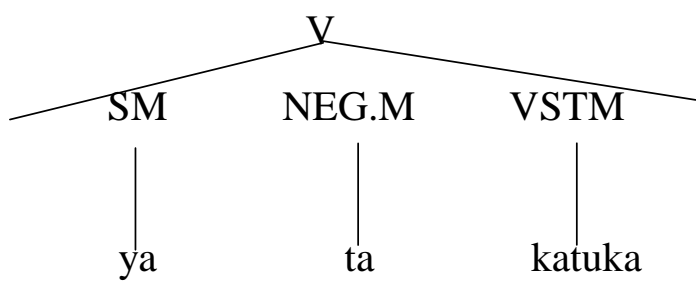

Gloss: let them not start off

\section{Key to abbreviations}

NEG.M: negative marker

In 34, 36, and 38 under SDTBEM, the imperative verbs undergo vowel coalescence. In each of these cases the low central vowel /a/ and the high front vowel /i/ fuse into a long mid front vowel /ee/ [e:] and the resultant imperative verbs are eebomba 'let him/her not work' in (34), eeingila 'let him/her 
not enter' in (36) and beeima'let them not start off' in (38). In 35 and 37 under STDBEM, the imperative verbs have undergone Semivocalisation; in both cases, the high back vowel /u/ becomes the voiced labio-velar approximant $/ \mathbf{w} /$ in the environment before the high front vowel $/ \mathbf{i} /$. In 35 , the imperative verb u-i-isa becomes wiisa 'don't come' and, in this case, there is a long high front vowel /ii/ [i:] after the voiced labio-velar approximant /w/. In wiisa, the first high front/i/ is the negative particle and the second one begins the verb stem, isa. Similarly, in 37, the high back vowel /u/ becomes the voiced labio-velar approximant /w / in the environment before the high front vowel /i/ and, therefore, the imperative verb mu-i-lya becomes mwilya 'don't eat': the high front vowel /i/ in this verb is the negative particle.In these circumstances, however, neither Vowel Coalescence nor Semi vocalisation occurs in the illustrations from 34 to 38 under RULMAM. However, there is the dropping or deletion of the low central vowel /a/ in the negative particle -ta- in 35 (ii): u-ta-iza, which becomes utiza'don't come' and in 36 (ii) a-ta-ingila which becomes atingila let him/her not enter' in the RULMAM imperatives.

The study, therefore, concludes that the morphological differences between the languages under study contribute to: (1) mutual unintelligibilitybetween Bemba and Mambwe speakers who have had no experience of each other's language and (2) the absence of linguistic convergence between Standard Bemba (STDBEM) and Rural Mambwe (RULMAM) despite that they are spoken in close proximity in the same geographical space.

\section{REFERENCES}

[1] Crystal, D. 2008. A dictionary of Linguistics and Phonetics. Oxford. Blackwell Publishers.

[2] Crystal, D. 1991. A Dictionary of Linguistics and Phonetics. Oxford: Blackwell Publishers.

[3] Halemba A. 1994. Mambwe-English Dictionary. Ndola: Mission Press.

[4] Hudson, R.A. 1980. Sociolinguistics. Cambridge: Cambridge University Press.

[5] Jimaima, H. 2016. Social Structuring of language and the mobility of Semiotic Resources across the Linguistic Landscapes of Zambia: A Multimodal Analysis. (Unpublished) PhD Thesis. Cape Town: University of Western Cape.

[6] Kamfuli, B.A. 2009. A Grammar of Verbal Extensions in Bemba. (Unpublished) MA dissertation. University of Zambia.

[7] Kandeke, T. 1990. A Handbook of Icibemba Synonyms. Lusaka: Kenneth Kaunda Foundation.

[8] Kangwa, N.K. 2007. A Study of English Derived loan words in Bemba. (Unpublished) MA dissertation. University of Zambia.

[9] Kashoki E.M. 1967. A Phonemic Analysis of Icibemba: A presentation of Bemba syllable structure, phonemic contrasts and their distribution. Michigan: Michigan: State University. USA.

[10] Kashoki, E.M. 1975. Migration and Language Change: The interaction of town and country. In Town and Country in Central and Eastern Africa, D. Parkin (ed.), 228 - 249. London: International Africa Institute.

[11] Kashoki E.M. 1977. Language in Zambia: Grammatical Sketches, volume. Lusaka: Grammatical Printers.

[12] Kashoki, E. M. \&M. Mann (1978). 'A general sketch of the Bantu languages of Zambia'. In S.I. Ohannessian\&M.E. Kashoki (eds.):Language in Zambia. London: International African Institute, pp. 47100.

[13] Kashoki, E.M \&Ohannessian, S. 1978. Language in Zambia. London: International African Institute.

[14] Kashoki, E. M, 2000. Notes on Mother Tongue Literacy Education Language Issues in Developing Countries. Stockholm:Stockholm University Centre for Research on Bilingualism.

[15] Kombo, D.K. \& Tromp, D.L.A.2006. Proposal and thesis writing: An introduction. Nairobi: Pauling's Publications Africa.

[16] Lumwanga, C.R. 2015. Some linguistic variations of Bemba: A Dialectological study of Standard Bemba, Luunda and Пumbo. (Unpublished), MA dissertation. University of Zambia.

[17] Mann M. 1999. An Outline of Bemba Grammar. Lusaka: Book world.

[18] Marten, L. \& Kula, N.C. 2008. Zambia: one Zambia, One Nation, Many Languages. In A Simpson (ed.), Language and National identity in Africa, pp.291-313.

[19] Mathews P.H. 2005. The concise Oxford Dictionary of Linguistics. Oxford: Oxford University Press.

[20] Musonda, $M$ \& Kashoki, E.M.1982. Lexical adaptability in Bemba and Luunda: Some implications for present-day communication. In Africa Social Research; No 34, 293-298.

[21] Scholarly articles for Mambwe at Ethnologue ( $18^{\text {th }}$ ed. 2015 
[22] Sims, G. W. 1959. An Elementary Grammar of Cibemba. Fort Roseberry: CMML.

[23] Spitulnik, D. \& Kashoki, E.M. 2001. Brief Bemba linguistic profile. In J. Garry \& C. Rubino eds.,Encyclopaedia of the World's Major Languages, Past and Present. New York: Rublin H.W. Wilson.

[24] Udema, S. 2004. The Theory of Lexical phonology. Munich: GRIN Publishing.

[25] Wakumelo, M.N. 2013. A Critical analysis of Zambia's language-in education policy: Challenges and lessons learned. In H. Mcllwraith (ed.)Multilingual education inAfrica: Lessons from the Juba language in education conference.pp. 127-146.London: British Council.

[26] Werner M. \& A.N. Tucker. 2009. Mambwe Proverbs. Cambridge: Cambridge University Press.

[27] Zambia Central Statistical Office (ZCSO). 2002/2010 Census of Population and Housing: National Analytical Report. Lusaka: Central Statistical Office.

\section{AUTHORS' BIOGRAPHY}

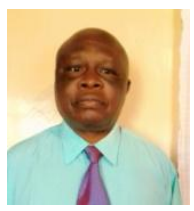

Chibwe Ronald Lumwanga, holds BAED (English and LAL) and MA (Linguistic Science) from the University of Zambia. He is a PhD studentat the same University.

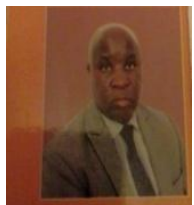

John Lubinda (PhD); he is a Senior Lecturer at the University of Zambia. He holds BA (French Pedagogy and Linguistics), MA (French and Applied Linguistics) from the University of Besançon (France), Diplome d' Etudes Approfodies, DEA (Phonetics, Phonology and French Linguistics), PhD (Phonetics, Phonology and French Linguistics) from the University of Strasbourg (France).

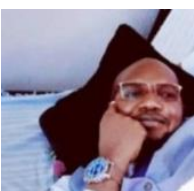

Hambaba Jimaima (PhD); he is a Lecturer at the University of Zambia and holds BAED (English and History), MA (Linguistic Science) from the University of Zambia and $\mathrm{PhD}$ (Linguistic Science) from the University of Western Cape (South Africa)

Citation: Chibwe Ronald Lumwanga, et.al. " A Contrastive Study of Bemba and Mambwe at Morphological Level" International Journal of Humanities Social Sciences and Education (IJHSSE), vol 8, no. 7, 2021, pp. 271-285. doi: https://doi.org/10.20431/2349-0381.0807030.

Copyright: (C) 2021 Authors. This is an open-access article distributed under the terms of the Creative Commons Attribution License, which permits unrestricted use, distribution, and reproduction in any medium, provided the original author and source are credited. 